\title{
Sex Education Through Classrooms Separation Policy Based on Gender in Islamic Culture
}

\author{
Eri Roslan; Norlinawati Abd Arshad \\ Institute for Social Science Studies, UPM, Seri Kembangan, Malaysia \\ https://doi.org/10.47814/ijssrr.v3i4.65
}

\begin{abstract}
The purpose of this study was to explore aspects of sex education on the application of Islamic elementary school which the female students' classrooms and male students' classrooms are separated. The research method used was qualitative research. The researcher was the primer instrument, but the researcher needed the other's instruments. Therefore, additional data collection techniques used were interviewing and observing. The kind of interviewing technique was used in this research was the in-depth interview. Participant observation passively was selected to observe the subject and object of the research as additional data collection technique. The results suggest that sex education can be applied early and realized through the concept of school implanted is the existence of separate classes. Thus, separation of classes by gender based on the aspect of religiosity is very influential to sex education and characters education. Sex education can be applied to an early age and manifested through the concept of a school planted that is the existence of separate classes.
\end{abstract}

Keyword: Children's Education; Elementary School; Islamic Elementary School; Classrooms GenderBased; Sex Education

\section{Introduction}

The development of the times, such as the existence of globalization, has given influence on various aspects of life. Influence arises side by side, ie negative influence and positive influence. Negative impacts on globalization on Indonesian culture have been widely felt, one of which is the change in behavioral development in children in elementary school level from the aspect of socio-cultural condition (Maslikhah, 2015; Rivauzi, 2015).

School as one of the educational environment has responsibility related to the condition. The school is an institution in charge of building character, accompanying the development of learners to take place in a reasonable, ideal, and normal (Isnaini, 2013; Rusydiyah, 2014; Irham and Wiyani, 2014: 32; Hadi, 2015). Primary school is a very important moment for the psychosocial development of learners and become the strongest socialization institution (Gibson and Mitchell, 2011: 81; Lin and Chen, 2016). The primary school education is expected that learners can have basic skills and support the achievement of development tasks well. 
The current moral crisis among young people includes fights for students, promiscuity, drug cases of students, students playing in shopping centers during class time, celebrating graduation with alchohol drinking, courtesy practices toward teachers and parents, both at school and in the community, cases of female abuse, female marginalization (Samad, 2013; Isnaini, 2013; Lan, 2015; Wathoni, 2016). The level of intimidation that occurs to children is predicted due to negative social behavior, feeling the sense of satisfaction from the surrounding environment, such as schools (Hilooğlu and Cenkseven-Önder, 2010). Problematic behavior and causing the weakness for social skills are due to emotional knowledge and emotional regulation in children (Upshur, Wenz-Gross, and Reed, 2013).

The children as individual are also a social creature that requires an interactive relationship to their daily life between people but also summarizes the whole of mankind regardless of religion, gender-male and female- and heredity (Samad, 2013). However, negative conditions on the behavior of troubled children to themselves and their social environment led to the need to balance the religious-based value system as a guide to strengthen the character (Said, 2015).

Islamic education in the form of Islamic schools is widely established in Southeast Asia, especially in Indonesia and serves to build a holistic generation (Zumrodi, 2015; Suyanta and Ikhlas, 2016; Wahyuningsih and Khuriyah, 2016). Building a holistic generation makes the aspect of moral, social and religious development of religious values very important. These aspects must be developed one of them on the issue of sex education (Solihin, 2015). Important sex education programs are provided early on for children. They have a positive contribution to achieving educational responsibilities, such as helping to fulfill developmental tasks according to environmental norms and demands (cultural aspects), preventing the occurrence of sexual deviation from children, preventing free sex, to avoid transmission of virus due to promiscuity (Hastuti, 2014; Solihin, 2015; Ratnasari and Alias, 2016; Wathoni, 2016).

Class separation by gender is becoming increasingly applied to schools in Indonesia. Generally, the separation is done in the learning process of religious boarding schools. However, the system is now widely used in public schools, both public and private schools (Hallaby and Hamama, 2017). Based on previous research, sex education has also been done in elementary school with Islamic education-based, namely Madrasah Ibtidaiyah (MI) of Mlarak and MI Ma'arif. The results of that reserach are about the implementing of sex education with some patterns: (1) Conducting activities of sex education to students indirectly, such as, insert sex education when teaching about morals. (2) Providing sex education services to students in accordance with the needs and circumstances that require, which is tailored to the teaching materials to avoid misunderstanding of learners. (3) Not providing sex education to learners at all with consideration of the negative side of the positive side. Then, MI of Mlarak and MI of Ma'arif in implementing sex education to the student of the conformity of teaching materials are delivered, and provide sex education to students periodically (Wathoni, 2016).

However, unlike this research that focuses on Islamic scholarship thinking about maintaining interaction of the opposite sex in a primary school in Surakarta. In addition, it is implemented in elementary schools with the concept of class division. The others facilities are separated too. Based on this background, the purpose of this study was to explore aspects of sex education in the implementation of Islamic educationbased primary schools that set separate classes of female students and male students in one same school.

\section{Research Method}

The research method used is qualitative research. Qualitative research is used. Researchers intend to deeply understand a phenomenon on the subject of research through various scientific methods by way of describing the data (Moleong, 2013: 6). 
This research has a place background in Surakarta, Central Java, that is in one elementary school, Diponegoro Islamic Elementary School. Elementary school selected is determined by purposive sampling. The reasons for the selection of the school became the background of the study in detail, namely: (1) Diponegoro Islamic Elementary School has a separate class of men and women class. (2) Diponegoro Islamic Elementary School is one of the schools based on Islamic education. (3) Diponegoro Islamic Elementary School often receives awards in Surakarta city of religious competition. (4) The school has diversity background based on their ethnics from Arabic, Javanese, and Madurese. Class separation policy is influenced by the school background founded by the Arab descendants and is also located in the territory of which the majority of the population is of Arab descent. Therefore, the application of Islamic values in school policy is one of the factors preserving the regulation. The object of this research is sex education and gender. The subject of the research is the students and teachers in elementary school.

Research data that is, data in the form of oral information related to result of interview with resource and activity data which is data of observation result. The data sources of this research are primary sources and secondary sources. Data collection techniques used in this study in addition to researchers, a primary gathering tool, are interviews, observations, and documentation. Researchers as the main instrument still use additional instruments in order to increase the completeness of possible data can not be obtained through the researcher (Nasution, 1996: 34).

The interview technique used was in-depth interview. In-depth interviews were conducted by means of question and answer by face to face with informants either using interview guidelines or not and interviewers and informants engaged in a relatively long social life (Bungin, 2007: 111). Informants in this interview activity, namely principals, classroom teachers, and some learners. The interview process is conducted both formally and informally. The data taken are class division policy, teacher perception about gender separation of class, and learners' thinking about the policy.

Observation technique used in this research is the type of observation passive role. The subject of his research, ie learners, both inside and outside the classroom. The data taken are interaction of students between women, women with men, and men.

Data analysis in this research use pattern Miles and Huberman (2007), namely: (1) data reduction, is arranging data presentation narration and conclusions of the parts of the problems that have been studied can be done. (2) presentation of data, that is arrangement of information on description of the form of complete narration so that can be done conclusion. (3) inference and verification. The conclusions made need to verified in order to be scientifically accountable. Data validity using triangulation method. Validity or validity of data is an effort to check the accuracy of research results through the application of certain procedures (Cresswel, 2013: 284).

The procedures of this research are: (1) Building a conceptual framework embodied in various shapes and sizes and is complex or elementary, and based on theory, descriptive or causal relations (Miles and Huberman, 2007: 31). (2) Formulate research problem of descriptive research problem (Miles and Huberman, 2007: 42). (3) Sample selection and limits data collection, is on decisions of people to be observed, settings, events, and social processes. Conceptual frameworks and research issues determine the focus and selected sample limits (Miles and Huberman, 2007: 49). (4) Instrument. Previous instrumentation that has been done for data collection should be improved on an ongoing basis.

Validity and reliability are highly dependent on the expertise of the researcher (Miles and Huberman, 2007: 69). (5) Data collection is done continuously with data analysis process (Miles and Huberman, 2007: 73). (6) Data analysis in accordance with the selected pattern and in the format of data presentation will continue to grow as influenced by the development of data obtained by researchers (Miles and Huberman, 2007: 151). (7) Interesting and testing conclusions. 
After drawing the conclusions, the findings are tested by triangulation, thus obtaining feedback from the informants (Miles and Huberman, 2007: 390).

\section{Discussion}

\section{Islam, Sex Education, and Children}

The teacher, in his interview indirectly stated that the environment and policies applied will affect how the strategy will be applied. Policies on the cultivation of school culture such as maintaining interactions between different sexes. Islamic law is related to the Muslim community. It is a manifestation of the way of life and behavior of the people of Allah SWT. Therefore, policymakers and the others have a role to support, so the rule of law, religion, social and culture is almost effective (Widyanto, 2011; Samad, 2013). Indirectly, sex education, Islamic education, and school policy as an educational institution are related. Furthermore, the informant stated that:

"... socialization between friends is also taught about adab (culture) compassion between different friends of the opposite sex".

Education applied to be one of the effort of planting character of early, knowledge about Islam, and about morality in association in Islamic culture. Moral is the same as the character or norm. It is directly driven by the brain. Character is the character, character, nature, habits, and way of thinking that characterize the individual to live and cooperate in various aspects and various environments (Isnaini, 2013; Rusydiyah, 2014).

The meaning of sexuality has been regarded as a public discussion. This suggests that the sociological significance of sex is not just about biological matters, but with relationships among people, the constantly changing perceptions of society and sex and its effects on sexual behavior; and also deals with issues of custom, religions, arts, morals, and law (Farihah, 2013; Solihin, 2015). Therefore, sexuality related to aspects of the development of elementary students consists of personal development, gender awareness, and maturity of relationships with peers (Hastuti, 2014). Knowledge of the age of sexual behavior can help teachers distinguish normal sexual behavior from problematic sexual behavior (Miragoli, Camisasca, \& Blasio, 2017). Education in Islam there is no discrimination between men and women as described in Al-Qur`an Surah Al-Mujadalah 1, Az-Zumar 9 and others (Zumrodi, 2015).

Sex education patterns of learners, namely: (1) Provide careful sex education so as not to lead to pornography, resulting in a false understanding of the child. (2) Including sex education materials on certain subject matter for class V and VI students only. (3) Emphasizes on the importance of maintaining the reproduction apparatus. (4) Emphasize the positive and negative efforts of sexual activity, along with information on the dangers of free sex. (5) Emphasizes the importance of self-preservation. It is more suitable to be conveyed through moral subjects (Wathoni, 2016).

Sex education is the teaching, awareness, and provision of information about sexual problems, so children can also prevent children from becoming victims of sexual harassment and prevent children from sexual misconduct (Ratnasari \& Alias, 2016). Sex education is very important to children caused by the following factors; (1) Children's lack of understanding about sex education due to lack of parental knowledge causes the child has no responsibility for sex or reproductive health anatomy. (2) Uncertainty of the child may cause vulnerability to the use of goods that are pornographic (Wathoni, 2016). 


\section{Sex Education through Class-Based Separation of Gender Equality}

Sex education in schools is very necessary to be taught from an early age, like in elementary school. The reasons for the importance of sexual education are in school; (1) Parents still consider negative thinking in teaching sex education to children. (2) Reducing the impact on promiscuity. 3) Directing children to learn knowledge about sex. 4) Understanding the effect of promiscuity. 5) Sexual education helps the child control sexual emotions (Wathoni, 2016).

Human life related to local Islamic culture. Islamic culture has two concepts, namely: (1) Local Islamic culture is a condition that has the specificity and uniqueness in terms of certain religious practices. Special conditions or uniqueness that can occur due to local culture around or based on the normative teachings of Islam itself. (2) The local Islamic culture has elements of local cultural, Islamic gathering, and interaction based on historical process (Rivauzi, 2015). The culture of Islam and the interaction of religious in the environment studied shows the application of the first and second concepts at once. Particularly in the second concept, it is characteristic that is discussed in this study. The school applies a separate class division of male and female students.

"... Here's a lot to win religious races. So,... relativitie [being one of the developed cultures]. And,.. for their behavior maintain the association for men and women ".

Thus, the policy of class separation of the basis of the gender differences between learners is an effort to plant early sex education such as the following interview footage of a separate class division policy on male and female learners.

"[Division of class policy separately] from the policy of Diponegoro Islamic elementary school's foundation. And about sex education and characters education.. In my opinion, ...the male students and female students who were set in a class [not mix], maybe their social interaction were higher than their classroo separated. If here, ... male and female students, the environment was also separated. Male students's classrooms below. Female students's classrooms above. Sometimes yes indeed, female students who start to become teenagers seeking attention to male students [gathered on stairs adjacent to classes for men ] you know ..."

Separation or class division by gender is an effort to introduce the sex world and to train learners to maintain one another. It is said to keep each other. Friendships that occur to the female' class, appear not to show a negative special pattern, such as mischief, or other. However, exceptions occur to a pattern of dissemination between different sexes. This is supported by interview researchers to the following teachers.

"[Separate class of male and female will] ... can limit (control) their interaction. The cafeteria is also separate. Familiarize from the 1st grade female student do not shake hands to male teacher and vice versa. O, this male's class, so [female students] can not be here, Ouw, this is not female's class. The male students's cafeteria here, the female cafeteria here. Here also has been accustomed to the first grade, female students shake hands with the female, male students shake hands with male students.... the second grade'students are still very young, sometimes forget..."

Separation or class division by gender as well as direct efforts of how to respect and love each other between friends. This is due to many studies that mention women always experience injustice or gender inequality in gender issues. However, in Islam, the concept of separate gender-based classes is the first step to implement Islamic science to learn children and to make children taking care of themselves.

Discrimination and gender bias formed by culture and misinterpretations of the Qur'an also play a role in understanding the concept of gender (Zumrodi, 2015). 
Gender-based education gap has become a concern. It is still important to be studied more deeply through the gender approach (Santoso, 2014; Denice, 2017). The approach is used as one of the solutions to address the gap between men and women on gender issues through decision-making and policy (Santoso, 2014). The subject of gender leads to the meaning of equal or equal status between men and women with notes without breaking the rules in Islamic law (Hadi, 2014).

\section{Conclusions}

The conclusions of the study suggest that sex education can be applied early and manifested through the concept of schooling that is the existence of separate classes. Thus, separation of classes by gender based on the aspect of religiosity is very influential to sex education and characters education. The recommendations of this research are: (1) It is necessary to conduct research with a wider scope, not only for one female's class in order to get the data onto the perception of male learners in the developing age of the same age. (2) Further research should also use quantitative or mixed research methods in order to complement the quality of research results.

\section{References}

Bungin, B. (2007). Penelitian kualitatif: komunikasi, ekonomi, kebijakan publik, dan ilmu sosial lainnya edisi kedua. Jakarta: Kencana.

Creswell, J.W. 2015. Research design: qualitative, quantitative, and mixed methods approaches. London: Sage Publication.

Denice, P. (2017). Back to school: Racial and gender differences in adults' participation in formal schooling, 1978-2013. Demography, 54:1147-1173. doi: 10.1007/s13524-017-0570-6

Farihah, I. (2013). Seksisme perempuan dalam budaya pop media Indonesia. Palastren, 6(1): 223-244.

Gibson, R.L. \& Mitchell, M. (2011). Bimbingan dan konseling. Yogyakarta: Pustaka Pelajar.

Hadi, S. (2014). Bias gender dalam konstruksi hukum Islam di Indonesia. Palastren, 7(1): 25-46.

Hadi, S. (2015). Menggagas pendidikan karakter responsif gender. Palastren, 8(2): 243-270.

Hallaby, S.F. \& Hamama, S.F. (2017). What is happening in this class?: kajian psikososial situasi di dalam kelas melalui perspektif gender. Jurnal Pendidikan Almuslim, 5(2), 77-80. DOI:

Hastuti, S. (2014). Pendidikan seksual anak di Tk dan Sd: Sebuah interaksi pelayanan bimbingan.

Makalah ini disampaikan dalam Seminar Sanata Dharma Berbagi "Pendidikan Seksual Anak di Masa Sekolah Awal", Yogyakarta, 8 September 2014. 1-11.

Hilooğlu, S. \& Cenkseven-Önder, F. (2010). The role of social skills and life satisfaction in predicting bullying among middle school students. Elementary Education Online, 9(3), 1159-1173. DOI: 
Irham, M. \& Wiyani, N.A. (2014). Bimbingan \& konseling: Teori dan aplikasi di sekolah dasar. Yogyakarta: Ar-Ruzz Media

Isnaini, M. (2013). Internalisasi nilai-nilai pendidikan karakter di madrasah. Al-Ta Lim Journal, 20(3), 445450. doi:http://dx.doi.org/10.15548/jt.v20i3.41

Lan, T.J. (2015). Perempuan dan modernisasi. Jurnal Masyarakat \& Budaya, 17(1), 17-28.

Lin, Y. \& Chen, Y.H. (2016). Primary school teachers' guidance role and competencies in Taiwan. International Journal of Education and Social Science 3(9), 76-80.

Maslikhah. (2015). Pendidikan Islam berkeadilan gender: menyoroti pemikiran Muhammad Atiyyah AlAbrashi. Palastren, 8(2): 321-338.

Miragoli, S., Camisasca, E., \& Blasio, P. D. (2017). Child sexual behaviors in school context: Age and gender differences. Journal of Child Sexual Abuse, 26(2), 213. https://doi.org/10.1080/10538712.2017.1280866

Moleong, L.J. (2013). Metode penelitian kualitatif. Bandung: PT. Remaja Rosdakarya.

Nasution, S. (1996). Metode penelitian naturalistik-kualitatif. Bandung: Tarsito.

Ratnasari, R.F. \& Alias, M. (2016). Pentingnya pendidikan seks untuk anak usia dini. Jurnal' Tarbawi Khatulistiwa', 2(2): 55-59.

Rivauzi, A. (2015). The education in local Islamic culture of maulid nabi tradition: a case study in Nurul Yaqin Ringan-Ringan Pakandangan Padang Pariaman boarding school. Al-Ta Lim Journal, 22(2), 165173. doi:http://dx.doi.org/10.15548/jt.v22i2.132

Rusydiyah, E. (2014). Character education through the constructivist design of Islamic education subject at Elementary School Pembangunan Jaya II in Gedangan Sidoarjo. Al-Ta Lim Journal, 21(3), 227-238. doi:http://dx.doi.org/10.15548/jt.v21i3.108

Said, N. (2015). Pendidikan akhlak muslimat melalui sya'ir: Analisis gender atas ajaran syi'ir muslimat karya Nyai Wanifah Kudus. Palastren, 8(2): 339-380.

Samad, D. (2013). Perempuan; Antara norma dan realita. Jurnal Ilmiah Kajian Gender, 1-11.

Santoso, W.M. (2014). Problematika kebijakan pengarusutamaan gender dalam mengatasi marjinalisasi perempuan. Jurnal Masyarakat \& Budaya, 16(3), 411-425.

Solihin. (2015). Pendidikan seks untuk anak usia dini (studi kasus di TK Bina Anaprasa Melati Jakarta Pusat). Jurnal Pendidikan Sekolah Dasar, 1(2): 56-73.

Suyanta, S., \& Ikhlas, S. (2016). Islamic education at Mughal Kingdom in India (1526-1857). Al-Ta Lim Journal, 23(2), 128-138. doi:http://dx.doi.org/10.15548/jt.v23i2.228

Upshur, C., Wenz-Gross, M., \& Reed, G. (2013). A pilot study of a primary prevention curriculum to address preschool behavior problems. J Primary Prevent, 34:309-327. doi: 10.1007/s10935-013-0316-1.

Wahyuningsih, R., \& khuriyah, K. (2016). A learning process evaluation model for the integrated Islamic elementary school. Al-Ta Lim Journal, 23(3), 201-213. doi:http://dx.doi.org/10.15548/jt.v23i3.245 
Wathoni, K. (2016). Persepsi guru madrasah ibtidaiyah tentang pendidikan seks bagi anak (Studi kasus di MI se-Kecamatan Mlarak). Kodifikasia, 10 (1): 203-227.

Widyanto, A. (2011). Pengembangan fiqh di zaman modern. Jurnal Ilmiah Islam Futura, X (2), 82-100.

Zumrodi. (2015). Pendidikan sensitif gender dalam Islam: telaah paradigmatis dalam sejarah intelektualisme islam Indonesia. Palastren, 8(2): 271-292.

\section{Copyrights}

Copyright for this article is retained by the author(s), with first publication rights granted to the journal.

This is an open-access article distributed under the terms and conditions of the Creative Commons Attribution license (http://creativecommons.org/licenses/by/4.0/). 